\title{
Article
}

\section{The Macroeconomic Determinants and the Impact of Sanctions on FDI in Iran: A Case Study}

\author{
Mehdi Rasouli Ghahroudi ${ }^{1}$ and Li Choy Chong ${ }^{2}$ \\ 1 International Business Institute for Management and Planning Studies (IMPS) \\ 2 International Business, Asia Research Center, University of St. Gallen, Dufourstrasse 50, CH-9000 \\ St.Gallen \\ * Correspondence: rasouli53@hotmail.com
}

\begin{abstract}
In this paper, we examine the impact of the macroeconomic determinants of foreign direct investment inflows. We also investigate the moderating role of sanctions in FDI inflows into Iran. The empirical results reveal that macro determinants such as infrastructure, exchange rate, inflation rate, investment return, and governance have a long-run impact on FDI inflows in Iran. Our findings also show that GDP growth rate and trade openness have no significant effect on FDI. Our results indicate that sanctions do not have a significant moderating role in the relationship between macroeconomic factors and foreign direct investment. Surprisingly, international sanctions have a positive relationship with FDI inflows in Iran. Furthermore, sanction has a positive impact on inflation rate and exchange rate in Iran. Finally, our findings show that sanctions have had a significant impact on Iran's economic growth in recent years due to increasing the severity level of sanctions.
\end{abstract}

Keywords: FDI inflows, sanctions, political stability, macroeconomic factors, GDP growth, Iran

\section{JEL Classification:}

\section{Introduction}

Foreign direct investment is an indispensable source of finance for developing countries, but policymakers must minimize their risks. FDI can help host countries to generate employment, technology diffusion, economic growth and sustainable development (UNCTAD, 2015). "The World Bank's edition of global development finance emphasize the importance of 'absorptive capacities' in the success of FDI. However, according to Alfaro et al, (2004) "absorptive capacities include (1) macroeconomic management (e.g. inflation and trade openness), (2) infrastructure (e.g. telephone lines and paved roads), and (3) human capital (e.g. share of labor force with secondary education and percentage of population with access to sanitation)". Furthermore, potential risk in developing countries should minimized through good governance and strong institutions, high absorption capacity and an effective legal framework (UNCTAD, 2015).

The inflows of FDI have shown an increasing trend over the last ten years of the 20th century, that doubles the world economy, trade flows (Rajana et al., 2008; Sinani \& Meyer, 2004). However, prospects for global FDI inflows are good, with a projected growth of 11 per cent to $\$ 1.37$ trillion in 2015. It is expected that global FDI flows may increase further to $\$ 1.5$ trillion in 2016 and to $\$ 1.7$ trillion in 2017. Thus, based on UNCAD's FDI forecast model and its survey related to multinational enterprises (MNEs) show an increase rise of FDI flows in the future.

According to UNCTAD (2017), weak oil prices and political uncertainty continue to effect on FDI inflows in West Asia including Iran. FDI flows to the region in 2016, dropped by 2 per cent to $\$ 28$ billion, as persistent low oil prices, political and geopolitical uncertainties, as well as regional conflicts. These factors have long been critical determinants of FDI inflows in West Asia. FDI figures for oil and gas do not give a detailed picture of FDI in the industry; however, foreign entry into oil and gas industries often includes unconventional arrangements such as management contracts and production sharing agreements. 
FDI figures for oil and gas do not give an accurate picture of the scale of MNEs' involvement in this industry, however, as foreign entry in oil and gas production often involves non-equity modes such as management contracts and production-sharing arrangements.

Depending on the levels of economic, social, and political development, there are many literatures on determinants of the FDI inflows (for example, Stack et al., 2017; Villaverde \& Maza, 2015; Naude' \& Krugell, 2007; Buckley et al., 2007; Asiedu, 2002; Dunning, 2002). The literatures found market size and growth (Bevan \& Estrin, 2004); availability of natural resources (e.g. Elheddad, 2017); skilled and qualified human capital (e.g. Kar 2013; Ndeffo, 2010; Lewin et al., 2009); quality of infrastructure (Cheng \& Kwan, 1999); and government policies (Cleeve, 2008); governance quality (Abdioglu et al., 2013); and political stability (Cleeve, 2012; Musibah, 2015). Therefore, these factors might help countries with slow or high economic growth. In the other word, countries that have FDI determinant factors are more likely to attract foreign direct investment. However, in the absence of FDI determinants, some countries might lose out in the attraction and retention of FDI (Cleeve et al, 2015).

While it is generally assuming that the boycott of bilateral direct trade between the United States and Iran has been the channel for economic losses for both sides, nothing could be further from the truth. For Iran, the real cost of direct trade losses is partly due to the impact of the decline in FDI, capital inflows and joint ventures. The impact of these non-trade effects on Iran is significant and as a result, it will be difficult for Iran to go back to business as usual with the US and its allies when sanctions are lifted (Askari et al., 2002). Accordingly, in this study we attempt to explain the issues of sanctions and to shed light on the FDI determinants by examining some macroeconomic factors and the business environment in light of Iran's policymaking on its FDIs. However, this study would attempts to investigate the impact of macroeconomic factors and the imposed sanctions on Iran's capability of attracting FDI inflows.

\section{FDI inflows in Iran}

Iran is considered as an energy superpower. According to Goldman Sachs (2011), "Iran has the potential to become one of the world's largest economies in the 21st century". Iran as OPEC's second largest oil producer, possess approximately 94 billion barrels (10 percent of world oil reserves); and has 812 trillion cubic feet reserves of natural gas in the world (17 percent of total). Iran also has enormous mineral resources, including iron, coal, copper, sulfur, and zinc as well as gold. Thus, these natural resources generate a number of processing industries. However, in case of doing business with Iran, the political and currency stability considered as the most problematic factors. In addition, due to sanctions, adversity to access international financing is also a major concern.

According to recent policy in Iran, the development of non-oil exports is a priority. Iran has a broad domestic industrial base, an educated and motivated workforce, energy resources and geographical location advantages, which provides access to an estimated population of 300 million people in Caspian markets, Persian Gulf states and countries further east. According to UNCTAD, Iran has ranked sixth in FDI attraction in 2010. 
Table 1. Iran's economic factors (1980-2015).

\begin{tabular}{|c|c|c|c|c|c|c|}
\hline Year & $\begin{array}{c}\underline{\text { GDP }} \text {, current } \\
\text { prices } \\
\text { (billions } \underline{\text { IRR })}\end{array}$ & $\begin{array}{c}\text { Implied PPP } \\
\text { conversion } \\
\text { rate } \\
\text { (USD/IRR) }\end{array}$ & $\begin{array}{c}\text { GDP per capita, } \\
\text { PPP } \\
\text { (USD) }\end{array}$ & $\begin{array}{l}\text { Inflation index } \\
\text { (average } \underline{\text { CPI }})\end{array}$ & $\frac{\text { Current account }}{\underline{\text { balance }}}$ & $\begin{array}{c}\text { Population } \\
\text { (million) }\end{array}$ \\
\hline 1980 & 6,622 & 40 & 4,267 & 0.5 & -3.6 & 38 \\
\hline 1985 & 16,556 & 53 & 6,469 & 0.9 & -0.9 & 48 \\
\hline 1990 & 35,315 & 101 & 6,410 & 2.5 & -2.7 & 55 \\
\hline 1995 & 185,928 & 399 & 7,265 & 9 & 3.4 & 64 \\
\hline 2000 & 580,473 & 940 & 9,666 & 21 & 12.5 & 64 \\
\hline 2005 & $1,831,739$ & 2,025 & 13,036 & 40 & 15.4 & 69 \\
\hline 2010 & $4,333,088$ & 3,498 & 16,664 & 82 & 27.3 & 74 \\
\hline 2015 & $13,077,142$ & 9,788 & 16,918 & 253 & 6.9 & 79 \\
\hline
\end{tabular}

Source: IMF - World Economic Outlook Database (2015).

The years of government control over the economy and the lack of private investment coupled with the market liberalization and recent reforms have led to interesting business and investment opportunities in many sectors. However, there is no challenge in finding areas of the Iranian economy that require investment.

Despite the uncertainty about the nuclear energy policy, the level of technology and infrastructure available to many industries in Iran makes it possible to develop partnerships with foreign companies. In fact, the presence of MNCs in Iran has increased dramatically over the past 20 years, due to open regulatory policy that makes multinational corporations face less difficulty for investing in Iran (Soltani \& Wilkinson, 2011).

According to the "Vision 2025" plan of the Iranian government, within two decades (2025-2005), Iran needs $\$ 3.7$ trillion investment, of which $\$ 1.3$ trillion should be in form of foreign investment. Table (2) shown FDI inflows and outflows in the last six years.

Table 2. Iran FDI flows 2011-2016 (Millions of dollars).

\begin{tabular}{|c|c|c|c|c|c|c|c|c|c|c|c|c|}
\hline \multirow[b]{2}{*}{ Year } & \multicolumn{6}{|c|}{ FDI Inflows } & \multicolumn{6}{|c|}{ FDI Outflows } \\
\hline & 2011 & 2012 & 2013 & 2014 & 2015 & 2016 & 2011 & 2012 & 2013 & 2014 & 2015 & 2016 \\
\hline Iran & 4277 & 4662 & 3050 & 2105 & 2050 & 3372 & 227 & 1441 & 146 & 605 & 120 & 104 \\
\hline
\end{tabular}

The opening of the Iranian market for foreign investment can also create a new investment opportunity for the multinational corporations that invest in different sectors of production and services in the next decade of about $\$ 600$ billion to $\$ 800$ billion in Iran.

Foreign investors focus on several sectors of the Iran's economy including; oil and gas industries, vehicle manufacturing, copper extraction, petrochemicals, food and pharmaceuticals. Iran absorbed US $\$ 34.6$ billion financing for 485 projects from 1992 to 2009, and $\$ 24.3$ billion of foreign investment from 1993 to 2007.

However, Figure 1 demonstrate the trend of FDI inflows in Iran from 1990 to 2016 according to UNCTAD (2017) reports. 


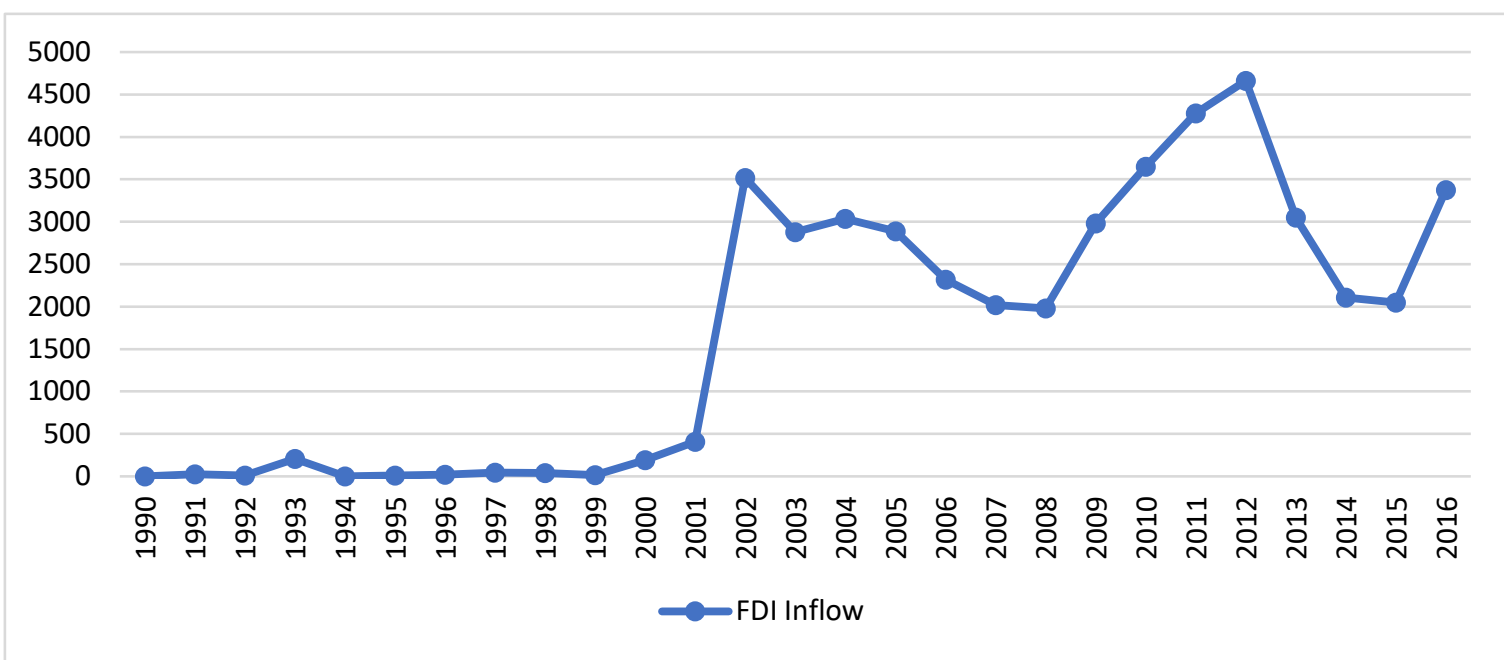

Figure 1. Iran FDI Inflow during the period 1990-2016.

Jafarnejad et al. (2009) studied the determinants of FDI inflows in Iran, using data for the period of 1991-2006. They have found a significant positive impact of openness of trade and GDP per capita have on FDI. Further, inflation, oil extraction and production had a negative correlation with FDI. Furthermore, their results also show that infrastructural factors, market size, research and development (R\&D), education and scientific output encourage FDI inflows. They concluded that FDI in Iran is more market-seeking and resource-seeking than an efficiency seeking. Soltani and Wilkinson's study (2010) examines international assignees' perceptions and experiences in a sample of Iranian-based MNC affiliates in high growth sectors. Their study indicates that the international assignees' perceptions of managing an MNE affiliate in Iran was often formed prior to their departure and their performance is strongly linked to the level of congruence between MNC and subsidiary's managerial orientation. Their finding reveals that performance tends to deteriorate when subsidiaries are requested to conform to MNC policies and practices. Table (3) shows Iran FDI stock in four periods (during 1990 to 2016).

Table 3. Iran FDI stock (Millions of dollars).

\begin{tabular}{|c|c|c|c|c|c|c|c|c|}
\hline \multirow[b]{2}{*}{ Year } & \multicolumn{4}{|c|}{ FDI Inflows Stock } & \multicolumn{4}{|c|}{ FDI Outflows Stock } \\
\hline & 1990 & 2000 & 2010 & 2016 & 1990 & 2000 & 2010 & 2016 \\
\hline Iran & 2039 & 2597 & 28953 & 48469 & 56 & 414 & 1713 & 3744 \\
\hline
\end{tabular}

(UNCTAD 2017).

\subsection{Gross Domestic Product}

The GDP growth rate, is a measure for the country's economic performance. The national economy development can be determined by criteria such as the amount of production, consumption, quality and diversity of goods, and other economic indicators (Musibah et al, 2015).

The growth of GDP can be as a determinant of FDI inflows to countries (UNCTAD, 1998). However, Sahoo (2006) asserts that countries with higher and sustained growth rate will receive more FDI flows.

Kahai (2011) argues that foreign investors are considering the size of the current market as well as potential for future growth in the market. In addition, the importance of GDP growth has been confirmed in many studies (Stack, 2017; Arbatli, 2011; Nonnemberg \& Mendonca, 2004; Nunnenkamp \& Spats, 2002).

Mina (2014) studied 52 middle-income countries and found an effect of GDP on FDI. In addidtion, Pradhan and Kelkar (2014) and Badr \& Ayed (2015) studies indicated a positive 
relationship between GDP and FDI inflow. further, favorable investment conditions and the rapid economic development in a host country would attract FDI.

H1. GDP growth has a positive impact on FDI inflows.

\subsection{Infrastructure}

Good infrastructure is essential in recipient countries to realize FDI benefits. The existence of developed infrastructure significantly reduces the cost of doing business for foreign investors and, as a result, increases their investment returns (Morriset, 2001). Therefore, good infrastructure is one of the characteristics of economic development. The development economics literature also emphasizes the need for access to basic infrastructures for poverty alleviation (Yamin and Sinkovics, 2009).

Iran has strong and extensive economic infrastructure. For instant, Iran's transportation network includes 12,000 kilometers of railways and 220,000 kilometers of roads. The country has nine commercial facilities in the south, including the Shahid Rajaee port in the north of the Strait of Hormuz, which deals with more than 80 foreign ports through 35 container lines. In addition, three commercial ports of the Caspian Sea in the north. Iran now has 167 Internet servers or 2.12 per million people and $31 \%$ of the people use the Internet. Furthermore, Iran has 29 million Landlines number and 65 million mobile phones number.

H2. Infrastructure has a positive impact on FDI inflows.

\subsection{Exchange Rate}

The literature acknowledges that there is a relationship between the exchange rate and the inflow of foreign direct investment. For instant, Clare \& Gang (2010), Kiyota \& Urata (2008) and Mowatt \& Zulu, (1999) have learned that the exchange rate could lead to fluctuations in foreign direct investment by affecting the cost of acquiring foreign currency. This is because the devaluation of the domestic currency against the value of the foreign currency will make the investment less expensive for a foreign investor in the host country. however, depreciation of domestic exchange rate will stimulate foreign direct investment inflows to that country (Musibah et al, 2015). In the other hand, If the value of a country's currency is decreasing, foreign investors are encouraged to buy assets at lower prices in that country (Blonigen \& Ma, 2011).

H3. Exchange rate has an impact on FDI inflows.

\subsection{Inflation Rate}

The rate of inflation represents the overall financial performance of host countries. In addition, high inflation indicates the government's failure to manage the country's budget, representing that the central bank failed to make an effective monetary policy (Hailu, 2010; Schneider \& Frey, 1985). Inflation is considered as an important element in the flow of foreign direct investment. In general, higher inflation rates will reduce FDI inflows (Bissoon, 2012; Kok \& Ersoy, 2009). However, there is a positive relationship between inflation and FDI (Ali, Khrawish, \& Siam, 2010; Azam \& Lukman, 2010). In contrast, studies such as Shahzad and Al-Swidi, 2013; Anyanwu, 2012; and Parajuli \& Kennedy, 2010, have found no significant relationship between inflation and FDI inflow.

H4. Inflation rate has an impact on FDI inflows.

\subsection{Political Stability}

In the case of political instability in a country, foreign investors reluctant to start any project unless they are confident that there is a favorable environment to encourage investment (World bank, 2011; UNCTAD, 2010; Brada et al., 2005).

Alcantara and Mitsuhashi (2013) reveal that political risk is one of the risks that affects the choice of the location, and indicating the unpredictability and instability of legal and political conditions in a host country. 
Host countries where the political structure or even the preferences of policymakers are unstable create more uncertainty and risk for MNCs, because changes in laws, taxes, and government permission after entry have led to undesirable shifts of their FDI (Henisz and Macher, 2004; Globerman and Shapiro, 2003; Delios and Henisz, 2003).

Shahzad et al. (2012) and Younis et al. (2008) reveal that political instability has significant impact on FDI inflow. However, it is assumed that the political stability can assist in attracting FDI inflows.

Madani and Nobakht, (2014) and Kim, (2010) assert that property rights and civil rights as proxies of political stability have key role in the attraction of FDI into the country.

H5. Political stability has a positive impact on FDI inflows.

\subsection{Trade Openness}

Traditional neoclassical theory states that the liberalization of trade and investment accelerates technological progress, improves labor efficiency, increase trade, and ultimately boosts economic growth (Cleeve et al, 2015). The positive association between trade openness and FDI has led to many studies in developing countries, for example, Little et al, (1970) studied the association of trade orientation and economic performance in developing countries. The more a country opens up its domestic market to external trade, the more the country can attract FDI. Trade openness is captured by the ratio of the country's exports plus imports to the GDP (Sahni, 2012; Nuneset al., 2006). Furthermore, researchers have analyzed the role of FDI in the growth of several economies to investigate the relationship between investment and growth. It is assumed that FDI is a significant source for obtaining capital, up-to-date technology, managerial skills, and enhanced marketing know-how.

In the host country, there are two main channels that determine the trade and FDI relationship. First, countries with a high degree of openness tend to attract more FDI inflows. Second, the inflow of foreign direct investment can affect trade flows through technology transfer and export expansion in the manufacturing sector (Chowdhury \& Mavrotas, 2006).

In the case of Iran, the total volume of imports increased by 189\% from \$ 13.7 billion in 2000 to $\$$ 39.7 billion in 2005 and $\$ 55.189$ billion in 2009 . Over the past five years, Iran's imports have fallen by $8.9 \%$ year-on-year, from $\$ 70.4 \mathrm{~b}$ in 2010 to $\$ 43.9 \mathrm{~b}$ in 2015, and are currently the world's 51 largest importers. The main trading partners of Iran are China, India, Germany, Japan, France, South Korea, Italy and Russia. Also, about $80 \%$ of machines and equipment in Iran are of German origin (Gheissari, 2009). Trade openness is considered as a key determinant of FDI and it is generally expected to have a positive influence on FDI inflows (Sahni, 2012; Sahoo, 2006; Asiedu, 2002).

H6. Trade openness has a positive impact on FDI inflows.

\subsection{Investment Return}

Foreign direct investment goes to countries with higher returns. But finding a suitable measure for the return on investment for developing countries is difficult due to the lack of a well-functioning capital market (Asiedu, 2002). Considering that profitability is one of the key determinants of investment. Therefore, the rate of return on investment in a host economy affects the investment decision. Further, the marginal product of capital is equal to the return on capital. However, capitalscarce countries have higher returns (Alavinasab, 2013, Asiedu, 2002).

Edwards (1990), Jaspersen et al. (2000) and Asiedu, (2002) employed the inverse of per capita income as a measure for return on investment, and their results showed that GDP per capita was inversely related to FDI. In contrast, Schneider and Frey (1985) reveals a positive relationship between GDP and FDI. It can be argued that GDP is providing better prospects for foreign direct investment in the host country.

H7. Investment return has a positive impact on FDI inflows. 


\subsection{Governance}

In recent years, discussions have been held on international development and political discourse within the framework of good governance, and for this reason the attraction of foreign investment is an important factor for the good functioning of the country's market. In fact, governments seeking to attract foreign direct investment should create favorable conditions for multinational corporations. On the other hand, the FDI decision-making process for investors and foreign organizations is very valuable in understanding the status of governance indicators in terms of transparency of administrative processes, reducing corruption and the peaceful environment (World Bank, 2006).

Morisset (2000) draw the conclusion that increase administrative costs due to corruption and bad governance, will reduce FDI inflows. Moreover, other studies argue that political and institutional factors are necessary to encourage FDI to developing countries (e.g. Stein and Daude, 2001; Stevens, 2000). In addition, Globerman and shapiro in 2002, assert that the governance infrastructure, including the nature of the legal system is an important determinant of FDI inflow in US.

Samimi and Ariani (2010) employed three governance indicators including political stability, corruption control and the rule of law for investigating the impact of a better quality of governance on FDI inflows in MENA region. They found that these indicators have a positive impact on FDI inflows and improve the governance.

In other study, Mengistu and Adhikary (2011) employed six indicators of good governance included political stability, government effectiveness and rule of law, the absence of violence and control of corruption. Their result reveal that these six indicators have impact on FDI inflows in 15 Asian countries and therefore, can increase the attraction of FDI.

H8. Governance has an impact on FDI inflows.

Table 4. Most recent macro studies on FDI.

\begin{tabular}{llll}
\hline \multicolumn{1}{c}{ Authors } & Sample & Variables & Finding \\
\hline Marie M & European & GDP, skills, trade cost, & The findings indicate the presence of both \\
Stack et al. & countries & distance, FDI intensity & vertical and horizontal motives of FDI with a \\
$(2017)$ & & cost & shift over time towards the latter. In \\
& & identifying the efficiency of FDI integration \\
& relative to maximum potential levels, the \\
& & stochastic frontier specification of the KK \\
& model indicates a mixed degree of FDI \\
& performance.
\end{tabular}

Mohamed M. MENA Political instability, The natural resource impact positively on Elheddad countries Corruption, labor force, resource FDI. The impact of corruption is on (2017) trade openness GDP, oil FDI. The result confirms the hypothesis of resource FDI foreign firm prefer to invest their money in corrupted areas which allow them more access to the natural resource and low taxes.

$\begin{array}{lllrl}\text { Jose' } & \text { European } & \text { R\&D expenditure, } & \text { The economic potential, labour market } \\ \text { Villaverde \& } & \text { regions } & \text { Human capital, Openness } & \text { characteristics, technological progress and } \\ \text { Adolfo Maza } & & \text { degreer } & \text { GDP, competitiveness exert a significant impact on } \\ (2015) & & \text { unemployment } & \text { rate, } & \text { FDI location patterns; in contrast, market size }\end{array}$


$\begin{array}{ll}\begin{array}{l}\text { Population, } \\ \text { productivity }\end{array} & \text { Labor } \\ \text { and labour regulation do not seem to play any } \\ \text { noteworthy role. }\end{array}$

Emmanuel A. Sub-

human capital, FDI

Cleeve et al. Saharan inflows

(2015)

Africa

Anwar Salem Yemen

Musibah et al.

(2015)

Kuzmina et al.

(2014)

Russia

FDI per capita,

quality

Governance

Bribes,

indicators:

Agencies,

Inspection

Police, and Criminal
Pressures,

Income per capita.

Strikes,

FDI, openness, growth

Khaled SAARC*

Guesmi \&

Frédéric

Teulon

(2014)

Chor Foon Malaysia

Tang et al.

(2014) rate, exchange rate, inflation rate

Human capital to have influenced, holding on the other non-traditional and traditional determinants of FDI. Irrespective of the indicator of educational attainment used and composition of control variables considered, the FDI effect of human capital was found to be robustly positive and significant.

The moderating variable, political stability is used together with other variables such as exchange rate, inflation rate, balance of payment and gross national income. The results show that political stability is critical for the future growth of Yemen economy.

Higher frequency of using illegal payments and higher pressure from regulatory agencies, enforcement authorities, and criminals, negatively affect foreign direct investment. Moving from the average to the top governance quality across Russian regions more than doubles the FDI stock.

The macroeconomic variables have long-term effect on the FDI inflows. However, economic instability and fluctuations in exchange rates have a negative effect on inward FDI flows and can therefore deter foreign investment.

Indicate that GDP, real exchange rate, financial development and macroeconomic uncertainty are positively related to inward FDI in the long-run. Corporate income tax and social uncertainty have a negative impact on inward FDI.

Mention that no significant relation is determined between the FDI inflow and GDP
FDI, GDP, exchange rate, financial development, corporate income tax, macroeconomic and social uncertainty

FDI

GDP 
Gokmen

(2014)

Abhilas India

Kumar

Pradhan \&

Suneel Kelkar

(2014)

$\begin{array}{lllr}\text { Priscila } & \text { Brazil and } & \text { FDI, GDP, Openness, } \\ \text { Gomes de Mexico } & \text { Exchange r } \\ \text { Castro et al. } & & \text { international commodities } \\ (2013) & & & \text { prices }\end{array}$

Arfan Pakistan

Shahzad

\& Abdullah

Kaid Al-Swidi

(2013)

Sajid Anwar Vietnam

\& Lan Phi

Nguyen

(2011)

$\begin{array}{lll}\text { Elizabeth } & 112 & \text { Democracy, FDI } \\ \text { Asiedu } & \text { developing } & \text { Natural resources } \\ (2011) & \text { countries } & \end{array}$

Formation Payment, Political growth in Turkey both in the short and long run.
GDP, CPI, Trade
Foreign Exchange Reserves (FOREX), Openness, Exchange Inflation (CPI) and Gross Capital Formation Rate, Foreign Exchange (GCF) are determinants of FDI inflows in Reserves, Gross Capital India over the years.

The importance of GDP and trade openness as attractive for FDI. Trade liberalization was a major attraction factor to FDI in both countries, and the size of the domestic market stood out as a determinant in Brazil. The foreign investment attraction depends on investments in policies that promote trade and economic growth.

FDI, GDP growth, The GDP growth rate, exports, imports and Exports, Imports, balance of payment have positive effects on Inflation Rate, Balance of FDI inflows. The GDP growth rate and balance of payment tends to be a determinant of FDI inflows when the moderating effect of the political stability is accounted for.

FDI ,exports, imports and

Both exports and imports are complementary to FDI. Geographical distance has a negative effect on trade volume and the impact of increase in per capita income on trade flows is large and significant.

Democracy facilitates FDI in countries where the share of natural resources in total exports is low, but has a negative effect on FDI in countries where exports are dominated by natural resources.

\section{*Six major countries in the South Asian Association for Regional Cooperation (SAARC).}

\section{Sanctions}

Sanctions are an economic weapon for countries to fulfill their foreign policy goals. Over the last century, various countries imposed many international economic sanctions against other nations (Hufbauer et al., 2007). Thus, Eaton and Engers (1992), Elliot and Hufbauer (1999), Davis and Engerman (2003), and van Bergeijk (2009) suggested various theoretical frameworks to explain how sanctions work. 
After the Iranian revolution, and after the hostage taking of US agents in 1979, the United States stopped its economic and diplomatic ties with Iran, banned the import of Iranian oil and froze approximately \$ 11 billion of its assets (Krauss, 2015 ). In 1996, the US government approved the Iranian-Libyan Sanctions Act (ILSA), which prohibited US (and non-US) companies from investing and trading more than $\$ 20$ million annually with Iran. Since 2000, items such as pharmaceuticals and medical equipment have been excluded from these sanctions (DeRosa and Hufbauer, 2012).

Iran's nuclear program has been debated since 2006, over suspicions of its intentions. The UN Security Council has imposed sanctions on selected companies associated with the nuclear program, which would cause the country's economic isolation (Gheissari, 2009). In particular, targeted sanctions on nuclear, missile and many military exports to Iran, and investment in oil, gas and petrochemicals, export of refined petroleum products, financial transactions, banks, shipping and insurance. In 2012, the European Union made its sanctions harder by joining the US oil embargo against Iran (Solomon, 2014). In addition, the last round of sanctions can bring about \$ 50 billion in lost oil revenue annually to Iran.

The UN Security Council has gradually established an international sanctions regime against Iran in 2005, which is committed by all member states.

In 2006, in the first resolution, the Security Council unanimously confirmed that measures include the embargo on materials and technology used in the production and enrichment of uranium, as well as in the development of ballistic missiles, and the blocking of financial transactions related to nuclear and ballistic missile programs. Subsequent resolutions in 2007 and 2008 blocked nonhumanitarian financial assistance to Iran. The fourth resolution approved in June 2010, adopted the U.S. approach, linking Iran's oil profits and its financial sector, including its central bank, to proliferation efforts, therefore subjecting them to international sanction.

Over the years, sanctions have serious consequences for the Iranian economy and people. The United States has made many international efforts to convince Western governments of the threat of Iran's uranium enrichment program and the development of nuclear weapons capability. However, Iran has denied this and believes its nuclear program is for civilian purposes, including power generation and medical purposes (Guzman, 2013).

Iran increasingly uses barter trade since it has been denied access to the international dollar payment system.

Monetary factors also cause problems, as sanctions cause a sharp fluctuation in the value of the Iranian Rial. In addition, a weak currency will make imports more expensive, and affect everything that is based on the Rial, including wages, stocks, homes, pensions, and gold. Thus, businesses also can hardly determine the price of goods and the value of their services.

It is therefore important that there is different between (i) the sanctions imposed on imports of nuclear-related products in 2006 and 2007, (ii) the sanctions imposed on non-oil exports in 2008, and (iii) the financial sanctions (Such as SWIFT, Banking) against Iran in 2012 (Haidar, 2015).

However, sanctions have been categorized based on their effect on Iranian economy: 1) Political sanctions: block the assets of individuals who are determined to support international terrorism. The list includes dozens of Iranian individuals and institutions, including banks, defense contractors. The Iran-Iraq Non-Proliferation Treaty (1992) prohibits anyone or entity that contributes to Iran's nuclear, chemical or biological weapons. 2) Trade sanctions: The United States bans sanctions that most US companies are banned from trading or investing in Iran until 1995. Although it slowed down in 2000, it almost finished decades later. The Obama administration has taken exception to the sanctions on the sale of consumer telecommunications equipment and software. 3) Energy sanctions: Energy Sanctions: The US's main focus is on reducing Iran's oil revenues. In this way, the pressure on the non-proliferation of nuclear weapons will increase. Prior to 2012, oil exports accounted for half the revenue of the Iranian government and made up one-fifth of the GDP. Extraterritorial sanctions target foreign companies that provide services or participate in investing in energy activities, including oil and gas and petrochemicals, supplying equipment used in oil refining as well as oil export activities, Such as shipbuilding, port operations, and shipping insurance.

4) Financial and Banking sanctions: US sanctions by the Treasury Department have sought to isolate Iran from the international financial system. Under the 2011 Comprehensive Iran Sanctions, 
Accountability, and Divestment Act (CISADA), foreign financial institutions, or subsidiaries that deal with banned banks prevented from conducting transactions in the United States and with US Dollars. In late 2011, the United States also prevented importers of oil imports to make payment through the Central Bank of Iran. Other aspects of the financial sanctions include limiting Iranians' access to foreign currencies, so that the funds from oil exports can only be used for bilateral trade with the buyer country or for access to humanitarian goods.

Askari et al (2002) believe that financial sanctions policies that are less discussed have had more important and long-term effects. Financial sanctions and policies that can be adequately measured include restriction on export financing, limiting the IMF and World Bank financing, reducing commercial financing, restricting Iran's debt-rescheduling efforts, and reducing FDI inflows (especially in the energy sector). However, effects that are not measurable include air travel restrictions, tourism, and risk assessment of Iran, which in turn affects foreign direct investment in non-energy sectors and other joint ventures.

The data released by the Central Bank of Iran in 2012 indicates a decline in the share of Iranian exports of petroleum products. Sanctions have reduced Iran's access to products needed for oil and energy, and forced many oil companies to stop their activities or exit from Iran. It also reduced oil production due to reduced access to the technologies needed to improve their facilities and performance. Many international companies are also reluctant to do business with Iran because of the fear of losing access to larger Western markets. However, we can state that in better political circumstances, such as non-US sanctions, it is likely to have much higher FDI .

H9. Sanctions moderates the relationship between macroeconomic factors and the FDI inflow in Iran.

Table 5. International sanctions against Iran (1984-2016).

\begin{tabular}{|c|c|c|c|c|}
\hline Date & Source & Name/No. & Elements of sanctions & $\begin{array}{l}\text { Type } \\
\text { sanctions }\end{array}$ \\
\hline $\begin{array}{l}\text { Jan. } \\
1984\end{array}$ & US & $\begin{array}{l}\text { State Sponsor of } \\
\text { Terror designation }\end{array}$ & - Banned arms sales and foreign assistance to Iran. & Political \\
\hline $\begin{array}{l}\text { Oct. } \\
1987\end{array}$ & US & $\begin{array}{l}\text { Executive Order } \\
12613\end{array}$ & - Banned import of all goods from Iran, including oil. & . Trade \\
\hline $\begin{array}{l}\text { Oct. } \\
1992\end{array}$ & US & $\begin{array}{l}\text { Iran-Iraq Arms } \\
\text { Proliferation Act }\end{array}$ & $\begin{array}{l}\text { - Sanctioned transfer of goods or technology related } \\
\text { to WMD and some conventional arms. }\end{array}$ & Political \\
\hline $\begin{array}{l}\text { Nov. } \\
1994\end{array}$ & US & $\begin{array}{l}\text { Executive Order } \\
12938\end{array}$ & $\begin{array}{l}\text { - Imposed export controls on sensitive WMD } \\
\text { technology. }\end{array}$ & Political \\
\hline $\begin{array}{l}\text { May } \\
1995\end{array}$ & US & $\begin{array}{l}\text { Executive Orders } \\
12957,12959\end{array}$ & $\begin{array}{l}\text { - Prohibited all U.S. investment in Iran, including in } \\
\text { oil sector. } \\
\text { - Banned export of American goods to Iran. }\end{array}$ & Trade \\
\hline $\begin{array}{l}\text { Aug. } \\
1996\end{array}$ & US & $\begin{array}{l}\text { Iran and Libya } \\
\text { Sanctions Act }\end{array}$ & $\begin{array}{l}\text { - Sanctioned companies that invest more than } \$ 20 \\
\text { million in Iranian oil sector. }\end{array}$ & Trade \\
\hline $\begin{array}{l}\text { Aug. } \\
1997\end{array}$ & US & $\begin{array}{l}\text { Executive Order } \\
13059\end{array}$ & - Expanded ban on exports to Iran. & Trade \\
\hline $\begin{array}{l}\text { Mar. } \\
2000\end{array}$ & US & Iran Non- proliferation Act & $\begin{array}{l}\text { - Sanctioned entities providing goods related to } \\
\text { WMD or ballistic missiles. }\end{array}$ & Political \\
\hline $\begin{array}{l}\text { Sep. } \\
2001\end{array}$ & US & $\begin{array}{l}\text { Executive Order } \\
13224\end{array}$ & $\begin{array}{l}\text { - Blocked property of terrorists and financial } \\
\text { supporters. }\end{array}$ & 1 Financial \\
\hline
\end{tabular}


Jun.

US Executive Order

2005 13382

Jul.

UN 1696

2006

Sep.

2006

Dec. UN 1737

2006

Feb.

Mar. UN 1747

2007

Jul. US Executive Order

$2007 \quad 13438$

Mar. UN 1803

2008

Jun. UN 1929

2010
- Blocked property of WMD proliferators.

Political

- Called upon states to exercise vigilance and prevent Political the transfer of material for nuclear and ballistic missile purposes.

- Sanctioned involvement in Iranian development of Political WMD/advanced conventional weapons.

- Codified U.S. trade ban.

- Banned export to Iran of all items, materials, Trade equipment, goods and technology related to nuclear activities or development of nuclear weapon delivery systems.

- Banned provision to Iran of technical or financial assistance related to nuclear activities.

- Banned Iranian export of nuclear-related equipment and material.

- Froze assets of individuals and companies involved in nuclear and ballistic missile programs.

- Banned export of sensitive nuclear and ballistic Political missile technology.

- Prohibited financial and technical assistance related to nuclear or missile activities.

- Froze assets and denied travel of designated individuals and companies.

- Banned export by Iran of any arms or related Political materiel.

- Expanded list of sanctioned individuals and companies.

- Blocked property of those involved in destabilizing Political Iraq.

- Expanded prohibitions on trade in sensitive nuclear Political equipment and materials.

- Banned travel by sanctioned individuals.

- Expanded list of sanctioned individuals and companies.

- Prohibited Iranian investment in foreign nuclear Trade activities.

- Banned export to Iran of major weapons systems and banned provision to Iran of technical or financial assistance related to acquiring these systems.

- Called on states to inspect all cargo to and from Iran if suspected of transferring illicit materials. 
- Called on states to prevent the provision of financial services that would facilitate Iranian sanctions evasion.

- Expanded list of sanctioned individuals and companies.

Jul. US Comprehensive Iran - Sanctioned sale to Iran of gasoline or supporting Energy 2010 Sanctions, Accountability \& domestic gasoline industry.

Divestment Act

Jul. EU Council Decision

$2010 \quad$ 2010/413/CFSP

Sep. US Executive Order

2010

Apr.

2011

Apr.

2011

Nov.

2011

Nov.

2011

Dec.

2011

Jan.

EU Council Decision

2012

13553

US Executive Order 13572

EU Council Decision 2011/235/CFSP

US Executive Order 13590 2012 2012/35/CFSP

\section{US USA PATRIOT Act}

US Section 1245, NDAA FY • Restricted export of Iranian oil. involved in human rights abuses. designation.
- Sanctioned foreign financial institutions connected with WMD or terrorism.

- Banned export to Iran of all arms and materiel.

- Prohibited financial and technical assistance related Energy to nuclear activities or weapons acquisition.

- Banned export to Iran of key equipment and technology related to oil and natural gas industry.

- Prohibited provision of insurance or re-insurance to Iranian entities.

- Expanded list of designated individuals and companies.

- Blocked property of those involved in human rights Political abuses in Iran.

- Blocked property of those involved in human rights Political abuses in Syria, including Iranians.

- Froze assets and denied travel of individuals Political

- Sanctioned contributing to maintenance or Energy expansion of Iranian petroleum resources.

- Designated Iranian financial sector as jurisdiction Financial of primary money laundering concern.

- Codified Section 311 Money Laundering

- Banned import, purchase or transport of Iranian Energy crude oil and petrochemical products.

- Prohibited provision of financing, insurance or reinsurance related to Iranian crude oil sale or transport.

- Prohibited export to Iran of equipment for petrochemical industry and provision of technical or financial assistance.

- Prohibited sale of gold, precious metals and diamonds to Iran. 


\begin{tabular}{|c|c|c|c|c|}
\hline $\begin{array}{l}\text { Feb. } \\
2012\end{array}$ & US & $\begin{array}{l}\text { Executive Order } \\
13599\end{array}$ & $\begin{array}{l}\text { - Blocked all Iranian government property under } \\
\text { U.S. jurisdiction. }\end{array}$ & Financial \\
\hline $\begin{array}{l}\text { Mar. } \\
2012\end{array}$ & EU & $\begin{array}{l}\text { Council Decision } \\
\text { 2012/152/CFSP }\end{array}$ & $\begin{array}{l}\text { - Banned provision of financial messaging services } \\
\text { to designated Iranian banks (i.e., denied access to } \\
\text { SWIFT). }\end{array}$ & Financial \\
\hline $\begin{array}{l}\text { Apr. } \\
2012\end{array}$ & US & $\begin{array}{l}\text { Executive Order } \\
13606\end{array}$ & $\begin{array}{l}\text { - Blocked property of those involved with human } \\
\text { rights abuses perpetrated through information } \\
\text { technology. }\end{array}$ & Political \\
\hline $\begin{array}{l}\text { Jul. } \\
2012\end{array}$ & US & $\begin{array}{l}\text { Executive Order } \\
13622\end{array}$ & $\begin{array}{l}\text { - Sanctioned foreign financial institutions that } \\
\text { facilitate petroleum sales. }\end{array}$ & Financial \\
\hline $\begin{array}{l}\text { Aug. } \\
2012\end{array}$ & US & $\begin{array}{l}\text { Iran Threat Reduction and } \\
\text { Syria Human Rights Act of } \\
2012\end{array}$ & $\begin{array}{l}\text { - Sanctioned support of petroleum sector. } \\
\text { - Mandated that Iran's oil revenue be locked up in } \\
\text { special escrow accounts. }\end{array}$ & Energy \\
\hline $\begin{array}{l}\text { Oct. } \\
2012\end{array}$ & US & $\begin{array}{l}\text { Executive Order } \\
13628\end{array}$ & $\begin{array}{l}\text { - Expanded Iran Threat Reduction and Syria } \\
\text { Human Rights Act }\end{array}$ & Political \\
\hline $\begin{array}{l}\text { Oct. } \\
2012\end{array}$ & EU & $\begin{array}{l}\text { Council Decision } \\
\text { 2012/635/CFSP }\end{array}$ & $\begin{array}{l}\text { - Banned purchase, import or transport of natural gas } \\
\text { from Iran. } \\
\text { - Banned export of shipbuilding technology. }\end{array}$ & Energy \\
\hline $\begin{array}{l}\text { Jan. } \\
2013\end{array}$ & US & $\begin{array}{l}\text { Iran Freedom and Counter- } \\
\text { Proliferation Act of } 2012\end{array}$ & $\begin{array}{l}\text { - Sanctioned involvement in Iranian energy, shipping } \\
\text { or shipbuilding, or provision of insurance or } \\
\text { reinsurance to shipping firms. }\end{array}$ & Trade \\
\hline $\begin{array}{l}\text { Jun. } \\
2013\end{array}$ & US & $\begin{array}{l}\text { Executive Order } \\
13645\end{array}$ & $\begin{array}{l}\text { - Sanctioned involvement in Iranian automotive } \\
\text { industry. } \\
\text { - Blocked assets of banks doing business in Rials, the } \\
\text { currency of Iran. }\end{array}$ & Financial \\
\hline
\end{tabular}

Source: Belfer Center for Science and International Affairs, Samore (2015).

The United Nations Security Council Resolution (No. 2231) was adopted on July 20, 2015. Therefore, a plan to suspend and eventually abolish United Nations sanctions with provisions to reimpose UN sanctions in case of non-performance by Iran. Under the Joint Comprehensive Plan of Action (JCPA), to suspend and eventually lifting UN sanctions, almost immediately the EU and the United States announced that sanctions already imposed on Iran were lifted. In practice, all sanctions imposed by the EU were removed. Some US sanctions, but not all of them, have been lifted. Between $\$ 100$ billion and $\$ 150$ billion of Iranian financial assets were released. In addition, trade sanctions that limited Iran's oil exports, as well as restrictions on imports of many goods, were also lifted.

Hence, it is expected that the lifting of the EU sanctions would have the greatest impact on macroeconomic policy in Iran and elsewhere, because oil accounts for 64 percent of Iran's export earnings, and Iran has a relatively high share (8 percent) of total world exports. In addition, the removal or reduction of inspections on imports and exports of Iran that were imposed as part of the regime of sanctions. Therefore, transport costs are expected to decrease in trade with Iran. Furthermore, due to the fact that the US and other partners have abolished restrictions on financial transactions services, Iran's import of financial services are expected to increase (Ianchovichina et al., 2016).

Nevertheless, on May 8, 2018, President Trump announced that the United States would withdraw from the JCPA agreement. 


\section{Data and Methodology}

The study tries to identify the determinant factors of foreign direct investment in the Iranian economy based on the secondary data sources for the period of 1991-2014. We seek to explain inward investment in the country based on a number of macroeconomic variables such as infrastructure, trade openness, governance, growth rate, political stability, inflation and exchange rates. These variables have already used in literature as factors that may influence FDI inflows. Since international sanctions made some restrictions on Iran's economy and those may affect FDI as well as macroeconomic factors, therefore, we study the moderating effect of sanctions on FDI during above period.

The data are on an annual basis and taken from various sources including UNCTAD statistics, the World Bank Indicator reports, Political Risk Services (PRS), Worldwide Governance Indicators (WGI), the International Telecommunication Union (ITU) database as well as Iran's Central Bank reports.

FDI INFLOW is actually used FDI. GDP GROWTH is the real gross domestic product (GDP) growth rate. The growth rate can be a representation of the wealth of a country. The good INFRASTRUCTURE will increase investment productivity and encourage FDI inflows (Asiedu, 2002). However, infrastructure measured by the number of mainline telephones per 100 of population, is used to proxy for the level of infrastructural development. GOVERNANCE measures the level of governance and institutional quality in a country. The data regarding the variable is taken from the World Bank Website and the Worldwide Governance Indicators. However, we study the impact of the six governance indicators on FDI inflow measured by the KKM Index, a broad governance measure developed by Kaufmann, Kraay and Mastruzzi (2009) which consists of the average of six indicators including voice and accountability, political stability and absence of violence, regulatory quality, government effectiveness, rule of law, and control of corruption.

Trade OPENNESS represents the degree of openness of a country to international trade and foreign investors. It is measured by the ratio of total imports and exports over gross domestic product. Further, it is recognized as a key factor in attracting FDI to the country (e.g. Cleeve et al, 2015; Sahni, 2012; Sahoo, 2006). INFLATION Correspond to the Consumer Price Index (CPI) change in years. It is a proxy for macroeconomic stability. Therefore, it shows the government's overall ability to manage the economy.

The high inflation rate creates uncertainty about the assets and liabilities of investors. Therefore, companies have less incentive to invest in high inflation countries (Abdellah et al., 2012). Thus, inflation has a negative impact on foreign direct investment. POLITICAL Stability is measured by ICRG, which is the measure of democracy published in the International Country Risk Guide (ICRG). Political Risk Services (PRS) publish the data, it reflect the extent to which elections are free and fair, and the degree to which the government is accountable to its electorate. However, the index ranges from one to six which a higher score implies more democracy and accountability (Asiedu and Lien, 2011). EXCHANGE Rate is time-variant real exchange rate. It represents competitiveness in international trade and the extent of market liberalization in the foreign exchange market (Yao and Zhang, 2001). The depreciation of a host country's currency makes host country's assets become interesting investment targets for foreign investors. In order to measure the INVESTMENT Return, we follow Jaspersen et al. (2000) and Asiedu (2002) to use inverse of per capita income as a proxy for return on investment. Thus, investing in countries with higher per capita income should have lower return, and therefore, real GDP per capita is inversely related to FDI inflow.

SANCTIONS have been categorized based on their effect on Iranian economy: 1) Political sanctions: frozen assets of entities determined to be supporting international terrorism, including individuals and institutions, defense contractors; and any person or entity that assists Iran in weapons development. 2) Trade sanctions: an embargo that prohibits most firms from trading with or investing in Iran. 3) Energy sanctions: sanctioning services and investment related to the energy sector, including investment in oil and gas fields, sales of equipment, and participation in activities related to oil and gas export. 4) Financial sanctions: isolating Iran from the international financial systems such as central bank, credits and swift system. 
However, to measure SANCTIONS variable, we first explored all sanctions against Iran. However, as shown in Table (5), during 1990 to 2014, about 25 sanctions by the United States (US), 6 sanctions by the European Union (EU) and 9 sanctions the United Nations Security Council (UN) have imposed against Iran.

Then, through interview, we have asked twenty economists to categorize sanctions; and determine the significance of each sanction based on its intensity and impact on Iran's economy. As a result, financial boycotts (found to be the most effective and toughest sanctions on Iran, then energy sanctions, and after that trade; and finally, political sanctions have less impact on Iranian economy. Therefore, we calculated the value of each year's sanctions effects by weighting them based on the type and the number of sanctions imposed for each year. For example, for 2006, there are three political sanctions and one trade sanction, therefore, the value of sanction variable for this year is 0.4 $(2 * 0.1+1 * 0.2)$. Moreover, since previous sanctions are still in place, the value of previous year added to the value of sanction in year 2006.

The research framework in Figure (2) shows the impact of selected macroeconomic factors on FDI inflows. However, we expect that the sanction have moderation role in the expected relationship of macroeconomic variables with the FDI inflows in Iran.

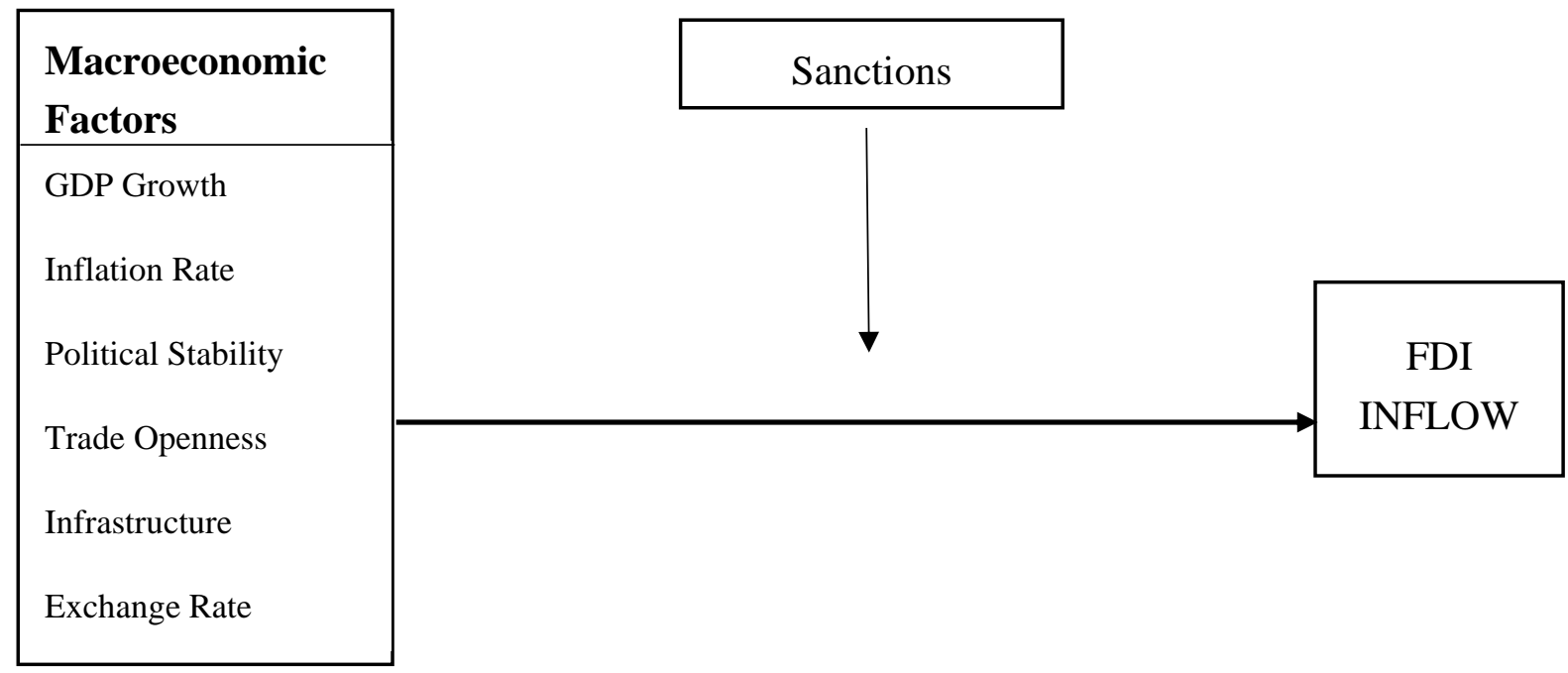

Figure 2. Research framework.

Having established co-integration among the variables, we investigate their impact on the FDI inflows. For this purpose, we propose Ordinary Least Squares (OLS) method to estimate long-term relationships.

\section{Results}

Spurious regression can be avoided if characteristics of time series data are analyzed at the start to know the nature of variables. These variables can either be stationary or non-stationary. However, we used Unit Root Test and Augmented Dickey Fuller (ADF) method in this study. As shown in Table 6, the dependent variable of FDI inflows and the variety of macroeconomic variables are stationary. 
Table 6. ADF unit root test results using the trend and intercept.

\begin{tabular}{|c|c|c|c|c|c|c|c|c|c|}
\hline \multirow[t]{2}{*}{ Variables } & \multicolumn{2}{|c|}{ Level } & \multicolumn{2}{|c|}{ 1st Diff } & \multicolumn{2}{|c|}{ 2st Diff } & \multicolumn{2}{|c|}{ 3st Diff } & \multirow[t]{2}{*}{ Lag } \\
\hline & $\mathrm{t}$ & Prob & $\mathrm{t}$ & Prob & $\mathrm{t}$ & Prob & $\mathrm{t}$ & Prob & \\
\hline FDI & -2.533 & 0.3107 & -4.237 & 0.0152 & & & & & 0 \\
\hline GROW & -3.894 & 0.0073 & & & & & & & 0 \\
\hline CPI & 2.638 & 0.9995 & 1.976 & 1.000 & 1.529 & 0.9999 & -4.391 & 0.0150 & 6 \\
\hline ICRG & -3.273 & 0.0993 & -2.681 & 0.0938 & -6.067 & 0.0005 & & & 3 \\
\hline OPEN & -2.655 & 0.2619 & -2.892 & 0.0624 & -5.812 & 0.0001 & & & 1 \\
\hline INFR & 2.088 & 0.9997 & -3.798 & 0.0374 & & & & & 2 \\
\hline $\mathrm{EXCH}$ & -1.863 & 0.6389 & -2.191 & 0.2148 & -5.566 & 0.0002 & & & 1 \\
\hline INVS & -1.865 & 0.3416 & -5.463 & 0.0002 & & & & & 0 \\
\hline GOVE & -3.430 & 0.0729 & -4.566 & 0.0018 & & & & & 1 \\
\hline SANC & 0.942 & 0.9996 & -3.274 & 0.0289 & & & & & 0 \\
\hline
\end{tabular}

FDI: FDI Inflow; GROW: GDP Growth; CPI: Consumer Price Index as a proxy for inflation; ICRG: International Country Risk Guide as a proxy for political stability; OPEN: Trade Openness; INFR: Infrastructure; EXCH: Exchange rate; INVS: Investment return; GOVE: Governance; SANC: Sanctions.

Table 7. Correlations.

\begin{tabular}{|c|c|c|c|c|c|c|c|c|c|c|c|}
\hline & Variables & 1 & 2 & 3 & 4 & 5 & 6 & 7 & 8 & 9 & 10 \\
\hline 1 & FDI & 1 & & & & & & & & & \\
\hline 2 & GROW & -.241 & 1 & & & & & & & & \\
\hline 3 & CPI & $.762^{* *}$ & $-.441^{*}$ & 1 & & & & & & & \\
\hline 4 & ICRG & $-.462^{*}$ & $-.413^{*}$ & -.353 & 1 & & & & & & \\
\hline 5 & OPEN & $.822^{* *}$ & -.211 & $.822^{* * *}$ & $-.530^{* *}$ & 1 & & & & & \\
\hline 6 & INFR & $.824^{* *}$ & $-.410^{*}$ & $.983^{* *}$ & $-.421^{*}$ & $.835^{* *}$ & 1 & & & & \\
\hline 7 & $\mathrm{EXCH}$ & $.685^{* *}$ & $-.512^{*}$ & $.946^{* *}$ & -.233 & $.632^{* *}$ & $.929^{* *}$ & 1 & & & \\
\hline 8 & INVS & .177 & .328 & -.123 & $-.641^{* *}$ & .151 & -.035 & -.212 & 1 & & \\
\hline 9 & GOVE & $-.835^{* *}$ & .280 & $-.818^{* *}$ & .360 & $-.878^{* *}$ & $-.803^{* *}$ & $-.705^{* *}$ & .091 & 1 & \\
\hline 10 & SANC & $.800^{* *}$ & $-.473^{*}$ & $.952^{* *}$ & -.215 & $.841^{* *}$ & $.930^{* *}$ & $.894^{* *}$ & -.256 & $-.892^{* *}$ & 1 \\
\hline
\end{tabular}

** Correlation is significant at the 0.01 level. ${ }^{*}$ Correlation is significant at the 0.05 level .

Table 8. Simple linear regression. 


\begin{tabular}{|c|c|c|c|c|c|c|c|c|c|}
\hline Variable & $\begin{array}{c}\text { GDP } \\
\text { Growth }\end{array}$ & $\begin{array}{c}\text { Inflation } \\
\text { Rate } \\
\end{array}$ & $\begin{array}{l}\text { Political } \\
\text { Stability }\end{array}$ & $\begin{array}{c}\text { Trade } \\
\text { Openness } \\
\end{array}$ & $\begin{array}{c}\text { Infra- } \\
\text { structure }\end{array}$ & $\begin{array}{c}\text { Exchange } \\
\text { Rate } \\
\end{array}$ & $\begin{array}{c}\text { Investment } \\
\text { Return } \\
\end{array}$ & Governance & $\begin{array}{c}\text { FDI } \\
\text { Inflow }\end{array}$ \\
\hline & - & & & & & & & & \\
\hline & $0.459 * *$ & $.964 * * *$ & -.299 & $.798 * * *$ & $.971 * * *$ & $.814 * * *$ & -.215 & $-.827 * * *$ & $.789 * * *$ \\
\hline Sanctions & $(-2.422)$ & (16.943) & $(-1.470)$ & $(6.215)$ & (19.223) & $(6.563)$ & $(-1.033)$ & $(-6.903)$ & (6.018) \\
\hline $\begin{array}{l}\mathbf{R} \\
\text { Square }\end{array}$ & .211 & .929 & .089 & .637 & .944 & .662 & .046 & .684 & .622 \\
\hline $\begin{array}{l}\text { Adjusted } \\
\mathbf{R}^{2} \\
\end{array}$ & .175 & .926 & .048 & .621 & .941 & .647 & .003 & .670 & .605 \\
\hline
\end{tabular}

The number in parenthesis is t-value.

Table 9. OLS Regression.

\begin{tabular}{|c|c|c|c|c|c|c|}
\hline Variable & Predictors & T value & Moderated & T value & Interactions & T value \\
\hline Constant & & -3.140 & & -2.141 & & -.050 \\
\hline GDP growth & .056 & .503 & .060 & .531 & -.023 & -.149 \\
\hline Political stability & .113 & .693 & .077 & .455 & $-.893 *$ & -1.849 \\
\hline Infrastructure & $1.968 * * *$ & 4.522 & $1.902 * * *$ & 4.253 & 1.130 & 1.285 \\
\hline Governance & $-.440 * *$ & -2.118 & $-.406^{*}$ & -1.896 & .167 & .437 \\
\hline Exchange rate & $.393 * *$ & 2.275 & .260 & 1.090 & .297 & .375 \\
\hline Investment return & $.238^{*}$ & 2.063 & $.300^{*}$ & 2.162 & .318 & 1.453 \\
\hline Inflation rate & $-1.818 * * *$ & -4.226 & $-1.988 * * *$ & -4.129 & -1.722 & -.673 \\
\hline Trade openness & .070 & .355 & -.086 & -.314 & -.333 & -.440 \\
\hline Sanctions & & & .521 & .823 & 1.018 & 1.206 \\
\hline GDP*SANC & & & & & -.489 & -1.301 \\
\hline ICRG*SANC & & & & & -1.044 & -1.496 \\
\hline INFR*SANC & & & & & 1.419 & .206 \\
\hline GOVE*SANC & & & & & -.661 & -1.769 \\
\hline $\mathrm{EXCH} * \mathrm{SANC}$ & & & & & $-2.402 *$ & -1.994 \\
\hline INVS*SANC & & & & & .117 & .627 \\
\hline CPI*SANC & & & & & 2.158 & 1.020 \\
\hline OPEN*SANC & & & & & -.989 & -1.619 \\
\hline R Square & .934 & & .937 & & .977 & \\
\hline Adjusted R Square & .899 & & .896 & & .924 & \\
\hline R Square change & .934 & & .003 & & .040 & \\
\hline F statistic & $26.505^{\prime}$ & & $23.127 * * *$ & & $18.458 * * *$ & \\
\hline
\end{tabular}

*** Significant at the 0.01 level; ${ }^{* *}$ Significant at the 0.05 level; ${ }^{* *}$ Significant at the 0.1 level.

The Durbin-Watson Statistic used to test for the presence of serial correlation among the residuals. The value of Durbin-Watson is 1.879 , approximately equal to two, indicating no serial correlation.

Table (8) demonstrate the effect of sanctions on macroeconomic factors. The result of simple linear regression reveal that sanctions has a positive significant impact on inflation rate $(t=16.943)$, trade openness $(t=6.215)$, infrastructure $(t=19.223)$, and exchange rate $(t=6.563)$. Nevertheless, 
international sanction against Iran has a negative significant impact on GDP growth $(\mathrm{t}=-2.422)$ and governance $(t=-6.903)$. Furthermore, sanctions has a positive impact on FDI inflows in Iran.

The regression results in Table (9) show that the macroeconomic variables explained approximately 90 percent variations in foreign direct investment in Iran. The value of the F-statistic shows that the equation has a good fit, that is, the explanatory variables are good explainer of changes in FDI inflow in Iran.

As expected, infrastructure is very significant with positive sign and statistically significant. Hisarciklilar et al (2006) also found this variable in their study in case of MENA region countries, with positive significant impact on FDI inflows. However, previous studies (e.g. Jafarnejad et al, 2011; Ramirez, 2009; Asiedu, 2005) indicate positive significant relationship between infrastructure and FDI.

The governance of the host country found to be significant in attracting FDI into Iran, and the variable has the negative sign. That means a 1 percent depreciation in the level of governance causes FDI to increase by approximately 0.44 . Thus, our result is inconsistent with other studies (e.g. Mengistu and Adhikary 2011; Samimi and Ariani, 2010; Globerman and Shapiro, 2002).

Moreover, the results illustrate that the exchange rate is significant in explaining changes in FDI. The finding is in line with other studies (e.g. Nurudeen, Auta, \& Wafure, 2011; Adam \& Tweneboah, 2009; Kaya \& Yilmaz, 2003). Accordingly, they found a positive impact of exchange rate on FDI inflows. However, other such as Masayuki and Ivohasina (2005) found that exchange rate depreciation may encourage the inflow of foreign direct investment to the host country.

Furthermore, the results reveal that trade openness of the economy and political stability are statistically insignificant but positively related to foreign direct investment. A similar finding highlighted by Brewer (1983) indicated a very weak correlation between government instability and FDI. Other studies (Asiedu, 2002; Olibe \& Crumbley, 1997) also fail to show a statistical association between FDI and political instability. However, the result is in the context of developed countries (Jimenez et al., 2011; Bitzenis et al., 2009). Similarly, the results show that GDP growth has an insignificant effect on foreign direct investment in Iran. This is consistent with Abdel-Rahman (2002) results that indicate GDP growth rate has positive but mainly insignificant impact on FDI in Saudi Arabia. Lastly, error correction parameter is significant and correctly signed, implying that the variables are con-integrated, and that a long run relationship exists among the variables.

In addition, the estimation also illustrates that inflation rate in Iran has a significant negative effect on FDI inflows. Some studies (e.g. Bissoon, 2012; Parajuli \& Kennedy, 2010; Bouoiyour, 2007; Asiedu, 2006) reveal that high inflation will hinder FDI inflows. Furthermore, there is a positive significant relationship between inflation and FDI (Azam \& Lukman, 2010; Ali, Khrawish, \& Siam, 2010). In contrast, several studies (e.g. Shahzad \& Al-Swidi, 2013; Anyanwu, 2012; Parajuli \& Kennedy, 2010) reveal that the relationship between inflation and FDI is not significant.

Another result of estimation is that investment return of the economy has a positive relation with FDI inflows, and the variable is significant. The positive impact of investment return on FDI reflects the situation in the Iran's oil sector that has continued to attract more foreign investment regardless of the political situation in the country. Furthermore, the results have shown a negative effect of governance on FDI inflows; therefore, our OLS regression results are consistent with the empirical literature (e.g. Kuzmina et al. 2014); the worse the governance quality is the less foreign investment we observe in Iran.

A common explanation of this evidence would be that corruption and potential pressure create uncertainty for investors in terms of their future cash flows, acting as an additional tax and increasing the risks of business capture, thereby decreasing the attractiveness of a particular region (Kuzmina et al. 2014).

Moreover, the result in model (3) shows that when the sanctions moderates the relationship between macroeconomic determinants and FDI, political stability and exchange rate have a negative significant impact on FDI inflow in Iran. Similarly, Krifa-Shneider and Matei (2010) reported a negative association between political risk levels and FDI inflow. The negative association between political risk and FDI inflows has been supported by some studies (e.g. Acheampong \& Osei, 2014; Burger, M., et al., 2013; Solomon \& Ruiz 2012; Kim, H. 2010; and Asiedu 2006). However, despite the 
argument that political risk could minimize FDI inflow, some studies (e.g. Esew \& Yaroson, 2014; Samimi \& Rezanejad, 2013; Bitzenis, 2007; Block, 2000) have shown that political risks play a key role in the decision of the firm to invest abroad. Nevertheless, some authors (e.g. Li and Resnick 2003) fail to show a significant impact of political instability on the FDI inflows.

\section{Conclusions and Implications}

Following the literature, this paper examines the known macroeconomic factors from the literature in the context of Iran, which has a unique context, quite different from those of other countries, given its unique geographical and historical situation and especially the unique international sanctions faced by the country. A comprehensive research into the established FDI macroeconomic factors in Iran in the light of the unique international sanctions, would therefore throw new light on the subject, particular the impact of international sanctions on incoming FDIs in a country. This is obviously also a very important issue to post-revolutionary as well as post-sanctions Iran.

Our findings demonstrate that most of macroeconomic factors tend to impact on the FDI inflow into Iran. Gross \& Trevino (1996) state that countries which have high levels of GDP growth are highly inclined to increase foreign direct investment flows by attracting trust from multinational corporations (MNCs) and encouraging them to invest. However, according to Biglaiser \& DeRouen (2011), more economic development attracts investors and they believe that the potential market is for a high return on investment.

Further, there is a positive significant relationship between infrastructure and FDI. This imply that development of infrastructures will increase inflows of FDI to Iran (Alavinasab, 2013).

FDI investors are usually looking for location that have suitable infrastructure such as roads, transportation and telecommunications. Investing in developed host markets, can reduce investor's production costs and then increase their profits. Foreign investors in Iran have more focused on energy sectors including oil and gas, petrochemicals, as well as telecommunications, car manufacturing, and mine industries.

Javidan \& Dastmalchian (2003) have, however, indicated that there are two internal movements with totally different thoughts to determine the direction of the future of the country: those who are not opposed to development and consider it as a means to achieve religious goals; and those who feel that the survival of Islam and the progress of Iran require a more modern perspective. However, continued confrontation between the two streams has caused political instability and turmoil, and has slowed the progress of the country.

Our finding indicate that sanctions has a significant impact on governance. This imply that Circumvent of sanctions may lead to the corruption and bad governance, which increase administrative costs and therefore reduce FDI inflows. However, the governance affects the security of property rights, transparency and legal process.

Furthermore, the results indicate a negative effect of sanction on GDP. This may be due to embargos on Iran's oil and gas, and by which reducing oil exports. Along with dependency of real GDP growth in Iran is oil. Therefore, sanctions have had a significant impact on Iran's economic growth in recent years due to increasing the severity level of sanctions.

Additionally, sanction has a positive impact on inflation rate and exchange rate in Iran. When international financial sanctions hampered access to oil revenues, Iran experienced a currency crisis that led to a sharp decline in the Rial. On the other hand, the government faced a problem to increase foreign currencies for its import needs, since demand for foreign currencies exceeded supply, which in turn led to a depreciation of the Rial. Moreover, sanctions are not the major cause of exchange rate crisis in recent years.

Our results indicate that sanctions do not have a significant moderating role in the relationship between macroeconomic factors and foreign direct investment. Surprisingly, international sanctions has a positive relationship with FDI inflows in Iran. This means that, despite the sanctions, some of multinational companies have realized the opportunities in the Iranian market as a developing economy; and have invested in less-under-threatened industries. Moreover, the special conditions of 
Iran during the years after the Iraq-war, including the abundance of natural resources, geographic location, the young and educated population; and the growing economy, have set the country as one of the objectives of direct foreign investment.

However, over the years, sanctions have serious consequences for the people and the economy of Iran. Nevertheless, the impact of sanctions is often denied in the Iranian press.

Iran has taken measures to circumvent sanctions, in particular through using barter trade and with help of front countries or companies. Moreover, in response to the sanctions, the Iranian government has backed a " resistance economy," such as more domestic use of oil due to limited export markets and the use of alternative industries.

After, the agreement between Iran and the P5+1 in 2015, the so-called post-sanction era has begun in Iran.

In addition, sanctions relief will affect Iran's economy in four main ways: (1) the release of Iran's frozen funds abroad by 2015, which is over $\$ 100$ billion; (2) the lifting of the sanctions against Iran's oil exports; (3) allowing foreign companies to invest in oil and gas, automobiles, hotels and other parts of Iran; (4) permitting trade with the rest of the world and access to a global banking system, such as SWIFT. However, with lifting sanctions, prospects are brighter for Iran, with new opportunities arising in oil and gas, and investment in manufacturing industries. Iran's government have established several incentive programs in order to encourage foreign companies to invest to Iran.

In addition, the attitude toward providing incentives for attracting FDI among economists is widely different. Moreover, some economists (e.g., Blomstrom \& Kokko, 2003; Bora, 2002; Black \& Hoyt, 1989) argued that providing incentives will attract more foreign investment, create jobs, and provide access to new technologies; and will result to other social and economic benefits. Cleeve (2008) argue that incentive costs outweigh their benefits, and he believe that improvements in local infrastructure, political stability, and macroeconomic stability are better tools for stimulating foreign direct investment inflows.

Nevertheless, in order to maximize the benefits of sustainable development through FDI (and other external sources of finance), policy makers must be mindful of minimizing risks. Therefore, through good governance, stakeholder participation, creating relevant local capacities and increasing absorption capacity (entrepreneurship, technology, skills and communication); and creating an effective standards and regulatory framework, risks can be minimized (UNCTAD, 2015). Moreover, developing countries need to provide incentive packages to attract foreign investment (Pajunen, 2008).

Haidar (2015) assert that while export sanctions against Iran have not reduced total exports, but it has increased export costs. If the goal is to reduce total exports, export sanctions may not be effective in a global economy. He argued that sanctions might be less effective in globalized world because exporters can shift their exports from an export destination to the other. Thus, the idea that a country can impose trade sanctions on another does not necessarily prove the effectiveness of such sanctions, unless the country's exporters are not able to find alternatives and new business partners.

Foreign investors are more motivated to invest in the host country when they are certain that there is a proper market for their products. This can be achieved by creating a suitable environment and incentives for production activities. The Iranian government must strive to make more deregulation in its economy in order to attract more foreign direct investment. This is true since the inflow of foreign direct investment has increased since the introduction of the "investment incentive program" in 2005.

Hereafter, the Iran's government should strengthened the political institutions and adopt principles that will ensure stability within the polity. The sanctions on Iran and current crisis in the Middle East region has been a major obstacle to instability of Iran's economy. Thus, the restoration of peace in the region will in turn woo more foreign investment to Iran.

However, our results suggest that the government need to allow the exchange rate to depreciate, as this will reduce the price of some of the poor indigenous industries, thus attracting more foreign investment in the form of mergers and acquisitions. Furthermore, Iran needs to increase the competitiveness of the investment environment through investing more in infrastructure and 
ultimately increase the inflow of FDI. Finally, all this should accompanied with ongoing reforms in the Iranian economy.

\section{References}

1. Abdioglu, N., Khurshed, A., \& Stathopoulos, K. (2013). Foreign institutional investment: Is governance quality at home important? Journal of International Money and Finance, 32(1), 916-940.

2. Ahmed, A. D., \& Suardi, S. (2009). Macroeconomic Volatility, Trade and Financial Liberalization in Africa. World Development, 37(10), 1623-1636.

3. Alavinasab, S. M., \& Ph, D. (2013). Determinants of Foreign Direct Investment in Iran, 3(2), 258-270.

4. Albulescu, C. T., \& Ionescu, A. M. (2017). The long-run impact of monetary policy uncertainty and banking stability on inward FDI in EU countries. Research in International Business and Finance.

5. Alcantara, L. L., \& Mitsuhashi, H. (2012). Make-or-Break Decisions in Choosing Foreign Direct Investment Locations. Journal of International Management, 18(4), 335-351.

6. Alfaro, L., Chanda, A., Kalemli-Ozcan, S., \& Sayek, S. (2004). FDI and economic growth: The role of local financial markets. Journal of International Economics, 64(1), 89-112.

7. Allen \& Overy LLP. (2006). Foreign direct investment in Central and Eastern Europe. Retrieved from http://www.springerlink.com/index/63Q53V5T705K6JT7.pdf

8. Amal, M. (2016). Foreign Direct Investment in Brazil. Foreign Direct Investment in Brazil.

9. Anwar, S., \& Nguyen, L. P. (2011). Foreign direct investment and trade: The case of Vietnam. Research in International Business and Finance, 25(1), 39-52.

10. Asiedu, E., \& Lien, D. (2011). Democracy, foreign direct investment and natural resources. Journal of International Economics, 84(1), 99-111.

11. Askari, H. (2002). Economic sanctions and US international business interests. Middle East, (220).

12. Barbopoulos, L., Marshall, A., MacInnes, C., \& McColgan, P. (2014). Foreign direct investment in emerging markets and acquirers' value gains. International Business Review, 23(3), 604-619.

13. Bekhet, H. A., \& Al-Smadi, R. W. (2015). Determinants of Jordanian foreign direct investment inflows: Bounds testing approach. Economic Modelling, 46.

14. Belloumi, M. (2014). The relationship between trade, FDI and economic growth in Tunisia: An application of the autoregressive distributed lag model. Economic Systems, 38(2), 269-287.

15. Boateng, A., Hua, X., Nisar, S., \& Wu, J. (2015). Examining the determinants of inward FDI: Evidence from Norway. Economic Modelling, 47.

16. Castro, P. G. De, Fernandes, E. A., \& Campos, A. C. (2013). The Determinants of Foreign Direct Investment in Brazil and Mexico: An Empirical Analysis. Procedia Economics and Finance, 5(13), 231-240.

17. Chan, M. W. L., Hou, K., Li, X., \& Mountain, D. C. (2014). Foreign direct investment and its determinants: A regional panel causality analysis. Quarterly Review of Economics and Finance, 54(4).

18. Chang, S. C., \& Boontham, W. (2017). Post-privatization speed of state ownership relinquishment: Determinants and influence on firm performance. North American Journal of Economics and Finance, 41, $82-96$. 
19. Ciesielska, D., \& Kołtuniak, M. (2017). Outward foreign direct investments and home country's economic growth. Physica A: Statistical Mechanics and Its Applications, 482, 127-146.

20. Cleeve, E. A., Debrah, Y. A. W., \& Yiheyis, Z. (2015). Human Capital and FDI Inflow : An Assessment of the African Case, 74, 1-14.

21. Clifford K. (2015). A New Stream of Oil for Iran, but Not Right Away, The New York Times (July 14, 2015).

22. Conconi, P., Sapir, A., \& Zanardi, M. (2016). The internationalization process of firms: From exports to FDI. Journal of International Economics, 99.

23. Contents, T. O. F. (2014). International Journal of Production Economics Author Information Pack, 1-13.

24. Crinò, R., \& Ogliari, L. (2017). Financial imperfections, product quality, and international trade. Journal of International Economics, 104, 63-84.

25. Dean A. DeRosa \& Hufbauer G. C. (2012). "Normalization of Economic Relations". (U.S.) National Foreign Trade Council. November 21, 2008. Retrieved March 30, 2012

26. Development, F. F. O. R. (2015). FINANCING FOR DEVELOPMENT - FDI CAN BE AN IMPORTANT SOURCE OF EXTERNAL DEVELOPMENT FINANCING FOR LDCs, LLDCs AND SIDS, (20), 1-10.

27. Economic Cooperation Organization (ECO) Secretariat (2010). Statistics, Retrieved September 28, 2010.

28. Elheddad, M. M. (2017). What determines FDI inflow to MENA countries? Empirical study on Gulf countries: Sectoral level analysis. Research in International Business and Finance.

29. Ghahroudi, M. (2009). Ownership advantages, foreign investment and performance of multinational companies' $\quad$ subsidiaries, (March). $\quad$ Retrieved from http://www.tulips.tsukuba.ac.jp/limedio/dlam/B28/B2869843/1.pdf

30. Ghahroudi, M. R. (2011). Ownership Advantages and Firm Factors Influencing Performance of Foreign Affiliates in Japan. International Journal of Business and Management, 6(11), 119-137.

31. Ghahroudi, M. R., Turnbull, S., \& Hoshino, Y. (2010). Assets growth, foreign ownership and type of industry in multinational companies. International Business Research, 3(4), 244-259.

32. Gheissari, Ali (2009). Contemporary Iran: Economy, Society, Politics. USA: Oxford University Press. pp. 78 (Paperback edition). ISBN 0-19-537849-0.

33. Global Investment Trends Monitor (2015). Financing for development - FDI can be an important source of external development financing for LDCs, LLDCs and SIDs, United Nations, (20), 1-10.

34. Goldman Sachs, (2011). The N-11: More Than an Acronym". Goldman Sachs, Retrieved February 6, 2011.

35. Golub, S. S. (2003). Measures of Restrictions on Inward Foreign Direct Investment for OECD Countries. OECD Economic Studies, 2003(1), 85-116.

36. Guzman, Timothy A. (2013). "New Economic Sanctions on Iran, Washington's Regime Change Strategy". Global Research. Retrieved 5 May 2013.

37. Haidar, Jamal I. (2015). Sanctions and Export Deflection: Evidence from Iran. Paris School of Economics.

38. Halkos, G., Managi, S., \& Zisiadou, A. (2017). Analyzing the determinants of terrorist attacks and their market reactions. Economic Analysis and Policy, 54, 57-73. 
39. He, Q., \& Sun, M. (2014). Does fiscal decentralization promote the inflow of FDI in China? Economic Modelling, 43.

40. Herrera-Echeverri, H., Haar, J., \& Estévez-Bretón, J. B. (2014). Foreign direct investment, institutional quality, economic freedom and entrepreneurship in emerging markets. Journal of Business Research, 67(9), 1921-1932.

41. Hsiao, F. S. T., \& Hsiao, M. C. W. (2006). FDI, exports, and GDP in East and Southeast Asia-Panel data versus time-series causality analyses. Journal of Asian Economics, 17(6), 1082-1106.

42. Ianchovichina E., Devarajan Sh. \& Csilla Lakatos C. (2016). Lifting Economic Sanctions on Iran Global Effects and Strategic Responses, Policy Research Working Paper 7549, Middle East and North Africa Region, World Bank Group.

43. International Monetary Fund (2014). World Economic Outlook Database (Iran), Retrieved February 16, 2015.

44. Jay Solomon (2014). "Oil, Auto Companies Make Plans to Invest in Iran if Sanctions Ease". Wall Street Journal, Retrieved July 5, 2014.

45. Kahouli, B., \& Maktouf, S. (2015). The determinants of FDI and the impact of the economic crisis on the implementation of RTAs: A static and dynamic gravity model. International Business Review, 24(3).

46. Kaur, M., \& Sharma, R. (2013). Determinants of foreign direct investment in India: an empirical analysis. Decision, 40(1), 57-67.

47. Kinuthia, B. K., \& Murshed, S. M. (2014). FDI determinants: Kenya and Malaysia compared. Journal of Policy Modeling.

48. Koch, A.J., (2001). Selecting overseas markets and entry modes: two decision processes or one?, Marketing Intelligence \& Planning.

49. Kravis, I. and Lipsey, R. (1982). The location of overseas production and production for export by US multinationals firms, journal of International Economics, No.12, pp 201-223.

50. Kuzmina, O., Volchkova, N., \& Zueva, T. (2014). Foreign Direct Investment and Governance Quality in Russia. Available at SSRN 2432967, 42, 1-37.

51. Liang, F. H. (2017). Does foreign direct investment improve the productivity of domestic firms? Technology spillovers, industry linkages, and firm capabilities. Research Policy, 46(1), 138-159.

52. Lu, Y., Tao, Z., \& Zhu, L. (2017). Identifying FDI spillovers. Journal of International Economics, 107, 75-90.

53. Makino, S., \& Delios, A. (1996). Local knowledge transfer and performance: Implications for alliance formation in Asia. Journal of International Business Studies, 27(5): 905-927.

54. Mallampally, P., \& Sauvant, K. P. (1999). Foreign direct investment in developing countries. Finance \& Development (Vol. 36). Retrieved from http://libproxy.anderson.edu/login?url=http://search.ebscohost.com/login.aspx?direct=true\&db=buh\&AN $=1743833 \&$ site $=$ ehost-live\&scope $=$ site

55. Mellahi, K., Demirbag, M., \& Riddle, L. (2011). Multinationals in the Middle East: Challenges and opportunities. Journal of World Business, 46(4), 406-410.

56. Merz, J., Overesch, M., \& Wamser, G. (2017). The location of financial sector FDI: Tax and regulation policy. Journal of Banking and Finance, 78, 14-26. http://doi.org/10.1016/j.jbankfin.2017.01.001 
57. Mirzaie I. (2014). GOVERNMENT POLICY, INFLATION, AND EXCHANGE RATES IN THE ERA OF SANCTIONS: THE CASE OF CONTEMPORARY IRAN, Harvard economic review, http://harvardecon.org/?p=3106.

58. Moosa, I., (2002). Foreign Direct Investment, Theory, Evidence and Practice .London, Palgrave.

59. Moreira, S. B. (2009). THE DETERMINANTS OF FOREIGN DIRECT INVESTMENT: What is the evidence for Africa? Poiésis-Revista Do Programa de Pós-Graduação Em Educação, 2(1), 83-104.

60. Morschett, D et al, (2010). Decades of research on market entry modes: what we really know about external antecedents of entry mode choice? Journal of international management.

61. Nayak, D., \& Choudhury, R. N. (2014). A selective review of foreign direct investment theories. Asia-Pacific Research and Training Network on Trade Working Paper, (143).

62. Nordal, K. B. (2001). Country risk, country risk indices and valuation of FDI: A real options approach. Emerging Markets Review, 2(3), 197-217.

63. OECD (2004). The Impact of Trade Related Intellectual Property Rights on Trade and Foreign Direct Investment in Developing Countries, working party of the Trade Committee, No. 42.

64. OECD (2016). Country Risk Report.

65. Opperman, P., \& Adjasi, C. K. D. (2017). The determinants of private capital flow volatility in Sub-Saharan African countries. Research in International Business and Finance, 42(July), 312-320.

66. Paniagua, J., \& Sapena, J. (2014). Is FDI doing good? A golden rule for FDI ethics. Journal of Business Research, 67(5), 807-812.

67. Pegkas, P. (2015). The impact of FDI on economic growth in Eurozone countries. Journal of Economic Asymmetries, 12(2), 124-132.

68. Peng, M.W., Wang, D.Y.L. \& Jiang, Y. (2008). An institution based view of international business strategy: A focus on emerging economies, Journal of International Business Studies, in press.

69. Ramírez-Alesón, M., \& Fleta-Asín, J. (2016). Is the Importance of Location Factors Different Depending on the Degree of Development of the Country? Journal of International Management, 22(1), 29-43.

70. Saleh, A. S., Anh Nguyen, T. L., Vinen, D., \& Safari, A. (2017). A new theoretical framework to assess Multinational Corporations' motivation for Foreign Direct Investment: A case study on Vietnamese service industries. Research in International Business and Finance, (July), 0-1.

71. Salem Musibah, A., Shahzad, A., \& Hanim Bt Fadzil, F. (2015). Impact of Foreign Investment in the Yemen's Economic Growth: The Country Political Stability as a Main Issue. Asian Social Science, 11(4), 102-116.

72. Salim, A., Razavi, M. R., \& Afshari-Mofrad, M. (2017). Foreign direct investment and technology spillover in Iran: The role of technological capabilities of subsidiaries. Technological Forecasting and Social Change, $122,207-214$.

73. Salim, A., Razavi, M. R., Afshari-Mofrad, M., Saleh, A. S., Anh Nguyen, T. L., Vinen, D., Zueva, T. (2017). The determinants of FDI and the impact of the economic crisis on the implementation of RTAs: A static and dynamic gravity model. International Business Review, 24(1), 0-1.

74. Samore, G. (2015). Sanctions against Iran: A guide to targets, terms, and timetables, Belfer Center for Science and International Affairs, Harvard Kennedy School, Cambridge, MA 02138, http://belfercenter.org. 
75. Shahzad, A., \& Al-Swidi, A. K. (2013). Effect of macroeconomic variables on the FDI inflows: The moderating role of political stability: An evidence from Pakistan. Asian Social Science, 9(9), 270-279.

76. Shukla, P. (2011). Journal of World Business. Journal of World Business, 46, 242-252.

77. Soltani, E., \& Wilkinson, A. (2011). The Razor's edge: Managing MNC affiliates in Iran. Journal of World Business, 46(4), 462-475.

78. Stack, M. M., Ravishankar, G., \& Pentecost, E. (2017). Foreign direct investment in the eastern European countries: Determinants and performance. Structural Change and Economic Dynamics, 41, 86-97.

79. Stefan, D., Comes, C.-A., Zaman, G., \& Vasile, V. (2012). Macroeconomic Impact of FDI in Romania. Procedia Economics and Finance, 3(12), 3-11.

80. Stoian, C. (2013). Extending Dunning's Investment Development Path: The role of home country institutional determinants in explaining outward foreign direct investment. International Business Review, 22(3), 615-637.

81. Su, Y., \& Liu, Z. (2016). The impact of foreign direct investment and human capital on economic growth: Evidence from Chinese cities. China Economic Review, 37.

82. Sunde, T. (2017). Foreign direct investment, exports and economic growth: ADRL and causality analysis for South Africa. Research in International Business and Finance, 41, 434-444.

83. Tan, K. G., \& Tan, K. Y. (2015). Foreign direct investment and small and medium enterprises. Retrieved from http://www.worldcat.org/oclc/906011347

84. Tang, C. F., Yip, C. Y., \& Ozturk, I. (2014). The determinants of foreign direct investment in Malaysia: A case for electrical and electronic industry. Economic Modelling, 43, 287-292.

85. Temiz, D. and Gokmen, a. (2014). FDI inflow as an international business operation by MNCs and economic growth: An empirical study on Turkey. International Business Review, 23, 145-154.

86. Teulon, F., \& Saint-germain, B. (2014). Determinants of Foreign Direct Investments in the South Asian Association for Regional Cooperation.

87. The Business Year (2013). Organization for Investment, Economic and Technical Assistance of Iran.

88. The Global Competitiveness Report (2014). World Economic Forum, Retrieved September 5, 2014.

89. Trade, I. M. (2013). General Profile : Iran, 2012-2014.

90. UNCTAD (1999). World Investment Report, Geneva

91. UNCTAD (2000) World Investment Report, Geneva

92. UNCTAD (2013) World Investment Report, Geneva

93. UNCTAD (2014). World Investment Report 2014: Investing in the SCGs- An action plan.

94. UNCTAD (2015) World Investment Report, Geneva

95. UNCTAD. (2009). The Role of International Investment Agreements in Attracting Foreign Direct Investment to Developing Countries. UNCTAD Series on International Investment Policies for Development. 
96. Unctad. (2014). World Investment Report 2014: Investing in the SCGs- An action plan.

97. UNIDO (2010). United Nations Industrial Development Organization, An Overview of the Economy of the Islamic Republic of Iran, Retrieved September 24, 2010.

98. Vedia-Jerez, D. H., \& Chasco, C. (2016). Long-run determinants of economic growth in South America. Journal of Applied Economics, 19(1), 169-192.

99. Vernon, R. (1960). International Investment and International Trade in Product Cycle, the Quarterly Journal of Economics, No.80.pp.128-231.

100. Villaverde, J., \& Maza, A. (2015). The determinants of inward foreign direct investment: Evidence from the European regions. International Business Review, 24(2).

101. World Economic Forum (2016). Global Competitiveness Report, Retrieved September 28, 2016.

102. World Investment Report (2008). United Nations Conference, Country fact sheet :1-2.

103. Yamin, M., \& Sinkovics, R. R. (2009). Infrastructure or foreign direct investment? An examination of the implications of MNE strategy for economic development. Journal of World Business, 44(2), 144-157.

104. Yao, S., \& Wei, K. (2007). Economic growth in the presence of FDI: The perspective of newly industrializing economies. Journal of Comparative Economics, 35(1), 211-234.

105. Yoo, D., \& Reimann, F. (2015). Internationalization of Developing Country Firms into Developed Countries: The Role of Host Country Knowledge-Based Assets and IPR Protection in FDI Location Choice. Journal of International Management, (November 2015), 0-1

106. Zheng, J., \& Sheng, P. (2017). The Impact of Foreign Direct Investment (FDI) on the Environment: Market Perspectives and Evidence from China. Economies, 5(1), 8. 